\title{
Hubungan Pengetahuan Ibu Bekerja Tentang Manajemen Laktasi Dan Dukungan Tempat Kerja Dengan Perilaku Ibu Dalam Pemberian ASI Di Wilayah Kerja Puskesmas Pembantu (Pustu) Amplas Medan
}

\author{
Lusiana Gultom
}

\begin{abstract}
Abstrak
Air Susu Ibumerupakan nutrisi alamiah terbaik bagi bayi karena mengandung kebutuhan energi dan zat yang dibutuhkan selama 6 bulan pertama kehidupan bayi. Cakupan ASI eksklusif di seluruh dunia hanya36\% selama periode 2007-2014, di bawah target WHO yang mengharuskan cakupan ASI minimal 50\%. Penghambat pemberian ASI eksklusif adalah rendahnya pengetahuan ibu dan factor ibu bekerja. Penelitian ini bertujuan untuk mengetahui hubungan pengetahuan ibu bekerja tentang manajemen laktasi dan dukungan tempat kerja dengan perilaku ibu dalam pemberian ASI di wilayah kerja Puskesmas pembantu Amplas Medan.Jenis penelitian analitik dengan menggunakan data primer yang diperoleh melalui kuesioner. Objek penelitian adalah semua ibu bekerja yang mempunyai bayi usia 7 - 24 bulan, menggunakan metode total sampling yaitu 40 orang ibu bekerja. Data diolah menggunakan uji statistik Chi-Square.Hasil penelitian mayoritas ibu memiliki pengetahuan kurang tentang manajemen laktasi dan tidak ASI eksklusif sebanyak 15 orang $(93,8 \%)$, hasil analisa disimpulkan X2 hitung $>\mathrm{X} 2$ tabel $(18,55>5,991)$ dan $\mathrm{P}$ value 0,000 berarti ada hubungan pengetahuan ibu bekerja tentang manajemen laktasi dengan perilaku ibu dalam pemberian ASI. Mayoritas ibu bekerja tidak mendapatkan dukungan dari tempat kerja dan tidak ASI eksklusif sebanyak 19 orang $(82,7 \%)$, hasil analisa X2 hitung > X2 tabel $(19,66>3,841)$ dan $\mathrm{P}$ value 0,000 berarti ada hubungan dukungan tempat kerja dengan perilaku ibu dalam pemberian ASI.Diharapkan kepada ibu bekerja agar tetap memberikan ASI eksklusif kepada bayinya dengan memahami tentang manajemen laktasi dan tenaga kesehatan juga harus giat untuk berperan aktif dalam memotivasi ibu bekerja untuk tetap memberikan ASI ekslusif.
\end{abstract}

Kata Kunci : Pengetahuan, Dukungan Tempat Kerja, Pemberian ASI

Daftar Bacaan : $21(2009-2015)$

\section{PENDAHULUAN}

\section{A. Latar Belakang}

Air Susu Ibu (ASI) merupakan nutrisi alamiah terbaik bagi bayi karena mengandung kebutuhan energi dan zat yang dibutuhkan selama enam bulan pertama kehidupan bayi. Pertumbuhan dan perkembangan bayi dan balita sebagian besar ditentukan oleh jumlah ASI yang diperoleh,termasuk energy dan zat gizi lainnya yang terkandung di dalam ASI tersebut, serta untuk mengurangi morbiditas dan mortalitas bayi dan balita.

Beberapa hal yang menghambat pemberian ASI eksklusif diantaranya adalah rendahnya pengetahuan ibu dan keluarga lainnya mengenai manfaat ASI dan cara menyusui yang benar, kurangnya pelayanan konseling laktasi dan dukungan dari petugas kesehatan, faktor sosial budaya, gencarnya pemasaran susu formula, dan factor ibu yang bekerja (Dinkes,2008).

Berdasarkan data Badan Pusat Statistik (BPS), partisipasi perempuan dalam lapangan kerja meningkat signifikan. Selama Agustus 2006-Agustus 2007 jumlah pekerja perempuan bertambah 3,3 juta orang (BPS, 2008).

Menurut Depkes, menyusui merupakan hak setiap ibu tidak terkecuali pada ibu yang bekerja, maka agar dapat terlaksananya pemberian ASI dibutuhkan informasi yang lengkap mengenai manfaat dari ASI dan menyusui serta bagaimana melakukan manajemen laktasi. Selain itu diperlukan dukungan dari pihak manajemen, lingkungan kerja, dan pemberdayaan pekerja wanita sendiri (Fiddini, 2010).

Banyak ibu yang bekerja mengatakan hanya dapat cuti bekerja selama tiga bulan sehingga tidak bisa menyusui eksklusif dan tidak mengerti tentang manajemen ASI atau menyimpan ASI yang baik dan benar. Sehingga memutuskan untuk memberikan susu formula untuk memenuhi kebutuhan gizi bayi.

\section{B. Rumusan Masalah}

Rumusan masalah dalam penelitian ini adalah "Apakah ada hubungan pengetahuan ibu bekerja tentang manajemen laktasi dan dukungan tempat kerja dengan perilaku ibu dalam pemberian ASI di wilayah kerja Pustu Amplas Medan ?"

\section{Tujuan Penelitian}

\section{Umum}

Untuk mengetahui hubungan pengetahuan ibu bekerja tentang manajemen laktasi dan dukungan tempat kerja 
dengan perilaku ibu dalam pemberian ASI di wilayah kerja Pustu Amplas Medan

\section{Khusus}

a. Untuk mengetahui dukungan tempat kerja ibu dalam pemberian ASI di wilayah kerja Pustu Amplas Medan.

b. Untuk mengetahui perilaku ibu dalam pemberian ASI di wilayah kerja Pustu Amplas Medan.

\section{BAB IITINJAUAN PUSTAKA}

\section{a. Pengertian ManajemenLaktasi}

Manajemen laktasi adalah segala upaya yang dilakukan untuk menunjang keberhasilan meyusui. Ruang lingkup manajemen laktasi dimulai dari masa kehamilan, setelah persalinan, dan masa menyusui selanjutnya. Ruang lingkup manajemen laktasi periode post natal pada ibu bekerja meliputi ASI eksklusif, teknik menyusui, cara memerah ASI, menyimpan ASI perah dan memberikan ASI perah.

\section{b. ASI Eksklusif}

Air Susu Ibu (ASI) adalah cairan hidup yang mengandung sel-sel darah putih, imunoglobin, enzim dan hormon serta protein spesifik dan zat-zat gizi lainnya yang diperlukan untuk pertumbuhan dan perkembangan anak ASI eksklusif adalah pemberian ASI saja sejak bayi dilahirkan sampai sekitar 6 bulan. Selama itu bayi tidak diharapkan mendapatkan tambahan cairan lain seperti susu formula, air jeruk, air teh, madu dan air putih. Pada pemberian ASI eksklusif bayi juga tidak diberikan makanan tambahan seperti pisang, biskuit, bubur susu, bubur nasi, tim dan sebagainya. Pemberian ASI secara benar akan depat memenuhi kebutuhan bayi sampai usia 6 bulan, tanpa makanan pendamping.

Pemberian ASI secara eksklusif ini dianjurkan untuk jangka waktu sekuran-kurangnya 4 bulan, tetapi bila mungkin sampai 6 bulan. Para ahli menemukan bahwa manfaat ASI akan sangat meningkat bila bayi hanya diberi ASI saja selama 6 bulan pertama kehidupannya.

Sebagai tujuan global untuk meningkatkan kesehatan dan mutu makanan bayi secara optimal maka semua ibu dapat memberikan ASI eksklusif dan semua bayi diberi ASI eksklusif sejak lahir sampai berusia 4-6 bulan, bayi diberi makanan pendamping yang benar dan tepat, sedangkan ASI tetap diteruskan sampai usia 2 tahun atau lebih.

\section{Keuntungan Menyusu Eksklusif Secara Umum}

1. Memberikan nutrisi yang optimal dalam hal kualitas dan kuantitas bagi bayi.

2. Meningkatkan kecerdasan.

Manfaat ASI bagi Bayi

1. ASI mengandung protein yang spesifik untuk melindungi bayi dari alergi

2. ASI juga bebas kuman karena diberikan secara langsung

3. ASI lebih mudah dicerna dan diserap oleh usus bayi

4. ASI mengandung banyak kadar selenium yang melindungi gigi dari kerusakan
Manfaat ASI bagi Ibu

1. Membantu mempercepat pengembalian rahim ke bentuk semula dan mengurangi perdarahan setelah melahirkan.

2. Mengurangi biaya pengeluaran karena ASI tidak perlu dibeli.

3. Mengurangi biaya perawatan sakit karena bayi yang minum ASI tidak mudah terinfeksi.

\section{Komposisi Gizi Dalam ASI}

Jumlah total produksi ASI dan asupan ke bayi bervariasi untuk setiap waktu menyusui dengan jumlah berkisar antar 450-1200 ml dengan rerata 750-850 ml per hari.

Kandungan nutrisi dalam ASI jauh lebih tinggi jika dibandingkan dengan susu sapi. Kandungan protein dalam kolostrum jauh lebih tinggi dari pada dalam ASI.

\section{Cara Menyusui Yang Baik dan Benar}

1. Sebelum menyusui, ASI dikeluarkan sedikit dan dioleskan ke puting susu dan areola sekitarnya.

2. Bayi diletakkan menghadap ke perut ibu/payudara.

3. Payudara dipegang dengan ibu jari diatas dan jari lain menopang dibawah, jangan menopang puting susu dan areolanya saja.

\section{Posisi Menyusui}

Ada beberapa macam posisi menyusui, ibu dapat mengambil posisi yang tepat untuk menyusui sebagai berikut :

1. Ibu yang melahirkan secara spontan bisa lebih leluasa untuk memilih posisi menyusui, sambil duduk atau berbaring menyamping.

2. Posisi Menyusui Ibu Yang Melahirkan Melalui Persalinan Seksio Caesaria

3. Football position adalah posisi meyusui yang disarankan untuk ibu yang melahirkan melalui persalinan seksio caesaria.

4. Sama dengan ibu yang melahirkan dengan persalinan seksio caesaria. Football position (dengan cara seperti memegang bola) juga tepat untuk bayi kembar, dimana kedua bayi disusui bersamaan kiri dan kanan

5. Pada ibu-ibu yang memiliki ASI berlimpah dan memancar (penuh) dan alirannya deras, terdapat posisi khusus untuk menghindari agar bayi tidak tersedak.

\section{Pengeluaran ASI dengan Cara Memerah ASI}

\section{Tahapan Persiapan Memerah ASI}

1) Cuci kedua tangan ibu dengan benar dan menggunakan sabun.

2) Usahakan ibu rileks dan pilih tempat atau ruangan untuk memerah ASI yang tenang dan nyaman.

3) Kompres payudara dengan air hangat. Gunakan handuk kecil, waslap atau kain lembut lainnya.

4) Mulailah mengurut payudara. 


\section{Tahapan Memerah ASI dengan Tangan}

1. Letakkan ibu jari diatas areola dan jari telunjuk serta jari tengah dibawah sekitar 2,53,80 di belakang membentuk huruf $C$.

2. Tekan lembut ke arah dada tanpa memindahkan posisi jari-jari tadi. Payudara yang besar, anjurkan ibu untuk mengangkat payudara lebih dahulu, kemudian tekan kearah dada.

3. Buatlah gerakan menggulung (roll) dengan arah ibu jari dan jari-jari kedepan untuk memerah ASI keluar dari gudang ASI yang terdapat dibawah areola di belakang puting susu.

4. Ulangi gerakan-gerakan tersebut $(1,2,3)$ sampai aliran ASI berkurang.

5. Lakukan pada kedua payudara secara bergantian.

\section{PengeluaranASIdengan Pompa}

1. Tekanbolakaretuntukmengeluarkanudara

2. Letakkan ujung lebar tabung pada payudara dengan putting susu tepat di tengah, dan tabung benar-benar melekat pada kulit

3. Lepas bola karet, sehingga putting dan areola tertarik kedalam

4. Tekan dan lepas beberapa kali, sehingga ASI akan keluar dan terkumpul pada lekukan penampung pada sisi tabung

5. Cucilah alat dengan bersih, menggunakan air mendidih.

\section{Penyimpanan ASI}

1. Simpan ASI dalam botol atau gelas yang sudah di sterilakan terlebih dahulu dan tutup rapat-rapat.

2. Cantumkan jam dan tanggal ASI di perah.

Cara dan waktu pemberian ASI yang telah disimpan/didinginkan yaitu :

a. Tidak boleh direbus/dipanaskan diatas api karena zat-zat yang terkadung didalamnya dapat mati

b. ASI dapat didiamkan beberapa saat di dalam suhu kamar,

c. Berikan ASI perah dengan menggunakan sendok agar bayi tidak terbiasa menghisap dengan dot dan jadi sulit menyusu pada payudara.

\section{Pengetahuan IbuBekerja}

Setiap orang memiliki pengetahuan yang berbeda, pengatahuan yang dimiliki seseorang merupakan peranan penting dalam pekerjaannya. Dari pengalaman dan penelitian terbukti bahwa perilaku yang didasari oleh pengetahuan akan lebih langsung dari pada perilaku yang tidak didasari oleh pengetahuan.

Penyebab rendahnya pemberian ASI eksklusif adalah rendahnya pengetahuan ibu tentang ASI eksklusif, masalah dalam ASI seperti ASI tidak keluar. Selain itu pada ibu yang bekerja tidak tahu bagaimana memberikan ASI perahdan menyimpan ASI perah, factor lain karena ibu menyusui yang bekerja beranggapan ASI tidak cukup diberikan kepada bayi, dan bayi tidak akan merasa kenyang.

Faktor yang mempengaruhi

a. Pendidikan

b. Pekerjaan

\section{Dukungan Tempat Kerja}

Berdasarkan Berdasarkan undang-undang peraturan pemerintah RI No.33 Tahun 2012 tentang pemberian ASI eksklusif, salah satunya adalah pasal 30 ayat 3 yang isinya pengurus tempat kerja dan penyelenggara tempat sarana umum harus menyediakan fasilitas khusus untuk menyusui dan/atau memerah ASI sesuai dengan kondisi kemampuan perusahaan (Jika tidak, setiap pengurus tempat kerjadan/atau penyelenggara tempat sarana umum yang tidak melaksanakan ketentuan sebagaimana dimaksud dalam Pasal 30 ayat (1) dan ayat (3),atau Pasal 34, dikenakan sanksi sesuai dengan ketentuan peraturan perundang- undangan). Berkaitan dengan ibu bekerja yang memiliki bayi, pemerintah mempunyai kebijakan dan strategi mendorong perusahaan-perusahaan dalam mendukung pemberian ASI eksklusif pada pekerja wanita dengan menyediakan fasilitas yang mendukung peningkatan pemberian ASI ditempat kerja,

\section{Perilaku Ibu dalam Pemberian ASI}

Perilaku pemberian ASI adalah suatu tindakan aktif dari seorang ibu dalam pemberian ASI eksklusif yaitu tanpa makanan tambahan dari bayi lahir sampai berusia 6 bulan (Dinkes,2008) Rendahnya pemberian ASI banyak ditemukan di antara perempuan yang bekerja karena alasan seperti singkat cuti hamil, tempat kerja tidak memperbolehkan membawa bayi atau tidak ada privasi untuk menyusui bayi.

\section{Pengetahuan Ibu Bekerja Tentang Manajemen Laktasi Dan Dukungan Tempat Kerja Dengan Perilaku Ibu Dalam Pemberian ASI}

Beberapa hal yang menghambat pemberian ASI eksklusif diantaranya adalah rendahnya pengetahuan ibu dan keluarga lainnya mengenai manfaat ASI dan cara menyusui yang benar, kurangnya pelayanan konseling laktasi dan dukungan dari petugas kesehatan, faktor sosial budaya, gencarnya pemasaran susu formula dan faktor ibu yang bekerja.yang merupakan penyebab rendahnya pemberian ASI eksklusif adalah rendahnya pengetahuan ibu tentang ASI Eksklusif, masalah dalam ASI seperti ASI tidak keluar. Selain itu pada ibu yang bekerja tidak tahu bagaimana memberikan ASI perah dan menyimpan ASI perah, factor lain karena ibu menyusui yang bekerja beranggapan ASI tidak cukup diberikan kepada bayi, dan bayi tidak akan merasakan yang.

Yang merupakan penyebab rendahnya pemberian ASI eksklusif adalah rendahnya pengetahuan ibu tentang ASI Eksklusif, masalah dalam ASI seperti ASI tidak keluar. Selain itu pada ibu yang bekerja tidak tahu bagaimana memberikan ASI perah dan menyimpan ASI perah, faktor lain karena ibu menyusui yang bekerja 
beranggapan ASI tidak cukup diberikan kepada bayi, dan bayi tidak akan merasakan yang.

\section{c. Kerangka Konsep}

Kerangka konsep terdiri dari variabel bebas (Independen) dan varibel terikat (dependen). Variabel independen (bebas) adalah pengetahuan ibu bekerja tentang manajemen laktasi dan dukungan tempat kerja. Sedangkan perilaku ibu dalam pemberian ASI ditetapkan sebagai variabel terikat (dependen).

\section{METODE PENELITIAN}

\section{A. Jenis Penelitian dan Desain Penelitian}

Jenis penelitian ini merupakan jenis penelitian analitik dan desain penelitian menggunakan desain cross sectional, dimana data yang menyangkut variabel bebas (Independen) danvariabel terikat (dependen), akan disimpulkan dalam waktu bersamaan.

\section{B. Lokasi dan Waktu Penelitian}

Amplas Medan.

Penelitian ini dilakukan di wilayah kerja Pustu

\section{Waktu Penelitian}

Penelitian inidilakukan pada bulan Januari sampai Juli 2017.

\section{Populasi dan Sampel Penelitian}

Populasi adalah jumlah keseluruhan objek penelitian atau objek yang diteliti. Objek dalam penelitian ini adalah semua ibu bekerja yang mempunyai bayi usia7 - 24 bulan yaitu sebanyak 40 orang. Sampel adalah sebagian dari populasi.

\section{Jenis Dan Cara Pengumpulan Data}

Jenis data yaitu dalam bentuk data primer yang diperoleh melalui kuesioner.

Pengumpulan data dilakukan oleh peneliti dengan mendatangi Posyandu di wilayah kerja Pustu Amplas Medan dan mendatangi rumah responden.

Sebelum dilakukan pengumpulan data peneliti terlebih dahulu menjelaskan tujuan penelitian, kemudian meminta kesediaan untuk menjadi responden penelitian. Setelah responden menyetujui, peneliti akan meminta untuk mengisi informedconsent dan menjelas kan cara pengisian kuesioner.

\section{Pengolahan Dan Analisa Data}

Mengkodedata(coding)

Menyuntingdata(editing

Memasukkandata(entry)

Membersihkandata(cleaning)

Pen yajianData

\section{Analisa Data}

1. Analisa Data Univariat

2. Analisis Data Bivariat
HASIL PENELITIAN DAN PEMBAHASAN

A. Hasil Penelitian Karakteristik Responden

\begin{tabular}{|c|c|c|c|c|}
\hline $\begin{array}{l}\mathbf{N} \\
\mathbf{0}\end{array}$ & Karakteristik & $\begin{array}{c}\text { Frekuen } \\
\text { si } \\
\end{array}$ & $\begin{array}{c}\text { Persentase } \\
(\%)\end{array}$ & $\mathbf{N}$ \\
\hline 1. & Umur Ibu & & & $\begin{array}{l}4 \\
0 \\
\end{array}$ \\
\hline & 16-27 tahun & 22 & 55 & \\
\hline & 28-40 tahun & 18 & 45 & \\
\hline 2. & Umur Bayi & & & $\begin{array}{l}4 \\
0\end{array}$ \\
\hline & $7-15$ bulan & 19 & 47,5 & \\
\hline & 16-24 bulan & 21 & 52,5 & \\
\hline 3. & Pendidikan & & & $\begin{array}{l}4 \\
0 \\
\end{array}$ \\
\hline & Tidak pernah sekolah & 1 & 2,5 & \\
\hline & Tidak tamat SD & 1 & 2,5 & \\
\hline & Tamat SD & 2 & 5 & \\
\hline & Tamat SMP & 3 & 7,5 & \\
\hline & Tamar SMA & 18 & 45 & \\
\hline & $\begin{array}{l}\text { Tamat perguruan } \\
\text { tinggi }\end{array}$ & 15 & 37,5 & \\
\hline 4. & Pekerjaan & & & $\begin{array}{l}4 \\
0 \\
\end{array}$ \\
\hline & Karyawan & 12 & 30 & \\
\hline & Guru/dosen & 2 & 5 & \\
\hline & $\begin{array}{l}\text { Bidan/petugas } \\
\text { kesehatan }\end{array}$ & 2 & 5 & \\
\hline & Wiraswasta & 10 & 25 & \\
\hline & PNS & 5 & 12,5 & \\
\hline & Lain-lain (buruh,dsb) & 9 & 22,5 & \\
\hline
\end{tabular}

Distribusi umur responden menunjukkan sebagian besar responden merupakan ibu-ibu dengan usia 16 hingga 27 tahun yaitu sebanyak 22 responden (55\%)dan umur 28 hingga 40 sebanyak 18 responden (45\%). Distribusi tingkat pendidikan responden menunjukkan distribusi tertinggi adalah SMA yaitu sebanyak 18 responden $(45 \%)$ dan distribusi terendah adalah tidak tamat sekolah dan tidak tamat SD masing-masing 1 responden $(2,5 \%)$.

Analisa Univariat

Pengetahuan Ibu BekerjaTabel Distribusi Pengetahuan Ibu Tentang Manajemen Laktasi Di Wilayah Kerja Pustu Amplas Medan

\begin{tabular}{ccc}
\hline Pengetahuan & Frekuensi & Persentase (\%) \\
\hline Baik & 11 & 27,5 \\
Cukup & 13 & 32,5 \\
Kurang & 16 & 40 \\
\hline Jumlah & 40 & 100 \\
\hline
\end{tabular}

Berdasarkan tabel

diketahui bahwa distribusi pengetahuan ibu bekerja tentang manajemen laktasi mayoritas memiliki pengetahuan yang kurang yaitu sebayak 16 orang (40\%) dan minoritas memiliki pengetahuan baik sebanyak 11 orang $(27,5 \%)$.

Dukungan Tempat kerja

Tabel Distribusi Dukungan Tempat Kerja Di Wilayah Kerja Pustu Amplas Medan 


\begin{tabular}{ccc}
\hline $\begin{array}{c}\text { Dukungan Tempat } \\
\text { Kerja }\end{array}$ & Frekuensi & Persentase (\%) \\
\hline Mendukung & 17 & 42,5 \\
Tidak Mendukung & 23 & 57,5 \\
\hline Jumlah & 40 & 100 \\
\hline
\end{tabular}

Berdasarkan tabel

mayoritas ibu bekerja yaitu 23 orang $(57,5 \%)$ tidak mendapatkan dukungan dari tempat kerja untuk memberikan ASI eksklusif bagi bayinya dan minoritas hanya 17 orang ibu bekerja (42,5\%) yang mendapatkan dukungan dari tempat kerja untuk memberikan ASI eksklusif.

Perilaku Ibu Dalam Pemberian ASI

Tabel Distribusi Perilaku Ibu Dalam Pemberian ASI Di Wilayah Kerja PustuAmplas Medan

\begin{tabular}{ccc}
\hline Pemberian ASI & Frekuensi & $\begin{array}{c}\text { Persentase } \\
(\boldsymbol{\%})\end{array}$ \\
\hline Eksklusif & 19 & 47,5 \\
Tidak Eksklusif & 21 & 52,5 \\
\hline Jumlah & 40 & 100 \\
\hline
\end{tabular}

Berdasarkan tabel distribusi pemberian ASI dapat diketahui bahwa mayoritas ibu tidak memberikan ASI eksklusif kepada bayinya yaitu 21 bayi $(52,5 \%)$ dan minoritas sebayak 19 bayi $(47,5 \%)$ memberikan ASI eksklusif.

Analisa Bivariat

Hubungan Pengetahuan Ibu Bekerja Dengan Perilaku Ibu Dalam Pemberian ASI Di Wilayah Kerja Pustu Amplas Medan

Tabel Analisa Hubungan Pengetahuan Ibu Bekerja Dengan Perilaku Ibu Dalam Pemberian ASI Di Wilayah Kerja Pustu Amplas Medan

\begin{tabular}{|c|c|c|c|c|c|c|c|c|c|}
\hline \multirow{3}{*}{$\begin{array}{l}\text { Penge } \\
\text { tahuan }\end{array}$} & \multicolumn{4}{|c|}{$\begin{array}{l}\text { Perilaku Ibu Dalam } \\
\text { Pemberian ASI }\end{array}$} & \multirow{2}{*}{\multicolumn{2}{|c|}{ Jumlah }} & \multirow{3}{*}{$\begin{array}{c}\mathcal{X}^{2} \\
\text { Hitu } \\
\text { ng }\end{array}$} & \multirow{3}{*}{$\begin{array}{c}\chi^{2} \\
\text { Tab } \\
\text { el }\end{array}$} & \multirow{3}{*}{$\begin{array}{l}P \\
\text { Valu } \\
\mathrm{e}\end{array}$} \\
\hline & \multicolumn{2}{|c|}{ Eksklusif } & \multicolumn{2}{|c|}{$\begin{array}{c}\text { Tidak } \\
\text { Eksklusif }\end{array}$} & & & & & \\
\hline & $\mathbf{F}$ & $\%$ & $\mathbf{F}$ & $\%$ & $\mathbf{F}$ & $\%$ & & & \\
\hline \multirow{3}{*}{ Baik } & & & & & 1 & 10 & & & \\
\hline & 9 & 81,9 & 2 & 18,1 & 1 & 0 & & & \\
\hline & & & & & 1 & 10 & & & \\
\hline \multirow[t]{2}{*}{ Cukup } & 9 & 69,2 & 4 & 30,8 & 3 & 0 & & & \\
\hline & & & 1 & & 1 & 10 & 18,5 & 5,99 & 0,00 \\
\hline \multirow[t]{2}{*}{ Kurang } & 1 & 6,2 & 5 & 93,8 & 6 & 0 & 5 & 1 & 0 \\
\hline & 1 & & 2 & & 4 & 10 & & & \\
\hline Jumlah & 9 & 47,5 & 1 & 52,5 & 0 & 0 & & & \\
\hline
\end{tabular}

Ibu bekerja yang memiliki pengetahuan baik mayoritas memberikan ASI eksklusif kepada bayinya yaitu sebanyak 9 orang $(81,9 \%)$ dan dari 16 orang ibu bekerja yang memiliki pengetahuan kurang mayoritas tidak memberikan ASI eksklusif kepada bayinya yaitu sebanyak 15 orang $(93,8 \%)$.
Hubungan Dukungan Tempat Kerja Dengan Perilaku Ibu Dalam Pemberian ASI Di Wilayah Kerja Pustu Amplas Medan

Tabel Analisa Hubungan Dukungan Tempat Kerja Dengan Perilaku Ibu Dalam Pemberian ASI Di Wilayah Kerja Pustu Amplas Medan

\begin{tabular}{|c|c|c|c|c|c|c|c|c|c|}
\hline \multirow{3}{*}{$\begin{array}{c}\text { Dukungan } \\
\text { Tempat } \\
\text { Kerja }\end{array}$} & \multicolumn{4}{|c|}{$\begin{array}{c}\text { Perilaku Ibu Dalam } \\
\text { Pemberian ASI }\end{array}$} & \multirow{2}{*}{\multicolumn{2}{|c|}{ Jumlah }} & \multirow{3}{*}{$\begin{array}{c}X^{2} \\
\text { Hitung }\end{array}$} & \multirow{3}{*}{$\begin{array}{c}\mathbf{X}^{2} \\
\text { Tabel }\end{array}$} & \multirow{3}{*}{$\begin{array}{c}P \\
\text { Value }\end{array}$} \\
\hline & \multicolumn{2}{|c|}{ Eksklusif } & \multicolumn{2}{|c|}{$\begin{array}{c}\text { Tidak } \\
\text { Eksklusif }\end{array}$} & & & & & \\
\hline & $\mathbf{F}$ & $\%$ & F & $\%$ & F & $\%$ & & & \\
\hline $\begin{array}{l}\text { Mendukung } \\
\text { Tidak }\end{array}$ & 15 & 88,2 & 2 & 11,8 & 17 & 100 & & & \\
\hline Mendukung & 4 & 17,3 & 19 & 82,7 & 23 & 100 & 1966 & 3.841 & 0.000 \\
\hline Jumlah & 19 & 47,5 & 21 & 52,5 & 40 & 100 & & & \\
\hline
\end{tabular}

Berdasarkan tabel17 ibu bekerja yang mendapatkan dukungan dari tempat kerja mayoritas memberikan ASI eksklusif kepada bayinya yaitu sebanyak 15 orang $(88,2 \%)$ dan dari 23 orang ibu bekerja yang tidak mendapatkan dukungan dari tempat kerja mayoritas tidak memberikan ASI eksklusif kepada bayinya yaitu sebanyak 19 orang $(82,7 \%)$

\section{PEMBAHASAN}

Pengetahuan Ibu Bekerja Tentang Manajemen Laktasi Hasil analisa pengetahuan ibu bekerja tentang manajemen laktasi menunjukkan bahwa distribusi pengetahuan ibu bekerja tentang manajemen laktasi mayoritas memiliki pengetahuan yang kurang yaitu sebayak 16 orang (40\%) dan minoritas memiliki pengetahuan baik sebanyak 11 orang $(27,5 \%)$.

\section{Dukungan Tempat Kerja}

Distribusi dukungan tempat kerja menunjukkan bahwa mayoritas ibu bekerja yaitu 23 orang $(57,5 \%)$ tidak mendapatkan dukungan dari tempat kerja untuk memberikan ASI eksklusif bagi bayinya dan minoritas hanya 17 orang ibu bekerja $(42,5 \%)$ yang mendapatkan dukungan dari tempat kerja untuk memberikan ASI eksklusif.

\section{Perilaku Ibu Dalam Pemberian ASI}

Distribusi pemberian ASI menunjukkan bahwa mayoritas ibu tidak memberikan ASI eksklusif kepada bayinya yaitu 21 bayi $(52,5 \%)$ dan minoritas sebayak 19 bayi $(47,5 \%)$ memberikan ASI eksklusif. Salah satu faktor yang menyebabkan rendahnya pemberian ASI di wilayah kerja Puskesmas pembantu (Pustu) Amplas Medan adalah status ibu yang bekerja.

\section{Hubungan Pengetahuan Ibu Bekerja Tentang Manajemen Laktasi Dengan Perilaku Ibu Dalam Pemberian ASI \\ Dari hasil analisa bivariat pengetahuan ibu bekerja tentang manajemen laktasi dengan perilaku ibu dalam pemberian ASI dapat diketahui bahwa dari 40 orang ibu bekerja (responden), berjumlah 11 ibu bekerja yang memiliki pengetahuan baik sebanyak 9 orang $(81,9 \%)$}


mayoritas memberikan ASI eksklusif kepada bayinya dan dari 16 orang ibu bekerja yang memiliki pengetahuan kurang 15 orang $(93,8 \%)$ mayoritas tidak memberikan ASI eksklusif kepada bayinya.

\section{Dukungan Tempat Kerja Dengan Perilaku Ibu Dalam Pemberian ASI}

Dari hasil analisa bivariat dukungan tempat kerja dengan perilaku ibu dalam pemberian ASI dapat diketahui bahwa dari 40 orang ibu bekerja (responden), bahwa dari 17 ibu bekerja yang tempat kerjanya memberikan dukungan untuk memberikan ASI eksklusif mayoritas memberikan ASI eksklusif kepada bayinya yaitu sebanyak 15 orang $(88,2 \%)$ dan dari 23 ibu bekerja yang tempat kerjanya tidak memberikan dukungan untuk memberikan ASI eksklusif mayoritas tidak memberikan ASI eksklusif kepada bayinya sebanyak 19 orang $(82,7 \%)$.

\section{KESIMPULAN DAN SARAN}

\section{KESIMPULAN}

1. Distribusi pengetahuan ibu bekerja tentang manajemen laktasi mayoritas memiliki pengetahuan yang kurang yaitu sebayak 16 orang (40\%) dan minoritas memiki pengetahuan baik sebanyak 11 orang $(27,5 \%)$.

2. Distribusi dukungan tempat kerja menunjukkan bahwa mayoritas ibu bekerja yaitu 23 orang $(57,5 \%)$ tidak mendapatkan dukungan dari tempat kerja untuk memberikan ASI eksklusif bagi bayinya dan minoritas hanya 17 orang ibu bekerja $(42,5 \%)$ yang mendapatkan dukungan dari tempat kerja untuk memberikan ASI eksklusif.

3. Distribusi pemberian ASI dapat diketahui bahwa mayoritas ibu tidak memberikan ASI eksklusif kepada bayinya yaitu 21 bayi $(52,5 \%)$ dan minoritas sebayak 19 bayi $(47,5 \%)$ memberikan ASI eksklusif.

\section{SARAN}

1. Bagi Puskesmas Pembantu (Pustu) Amplas Medan Petugas Pustu Amplas Medan harus menjadi petugas yang giat untuk mempromosikan tentang manajemen laktasi kepada masyarakat agar mesyarakat semakin giat untuk memberikan ASI eksklusif kepada bayinya, terutama ibu bekerja agar kebutuhan ASI eksklusif bayi tetap terpenuhi meskipun ibu bekerja.

2. Bagi Instansi/Perusahaan Tempat Ibu Bekerja Petugas kesehatan yang bertugas di Pustu Amplas Medan seharusnya melakukan koordinasi dengan instansi/perusahaan untuk dapat menyediakan sarana maupun fasilitas serta mendukung kebijakan pemerintah tentang adanya ruang laktasi agar perusahaan yang memperkerjakan perempuan (ibu menyusui) ikut serta mendukung kegiatan laktasi bagi ibu bekerja.
3. Bagi Peneliti Selanjutnya Sebagai referensi bagi peneliti selanjutnya untuk meneliti variabel yang berbeda. 


\section{DAFTAR PUSTAKA}

Baston, Helen \& Hall, Jenifer. 2013. Postnatal. Jakarta : EGC

Dewi, V.N.L \& Sunarsih, Tri. 2014. Asuhan Kebidanan Pada Ibu Nifas. Jakarta : Salemba Medika

Fiddini, F. 2010. Gambaran Pengetahuan, Sikap dan Perilaku Ibu yang Bekerja Terhadap Pemberian ASI Eksklusif Pada Bayi. http://repository uinjkt ac.id dspace/handle/12345678/25746 diakses Jumat, 03 Maret 2017

IDAI. 2013. Manajemen Laktasi. Diakses Minggu, 19 Maret 2017

http://www.idai.or.id/artikel/klinik/asi/manajemen-laktasi Infodatin, 2014. Situasi dan Analisis ASI Eksklusif. Pusat Data dan Informasi Kementerian Kesehatan RI Tahun 2014

Kristiyanasari, Weni. 2009. ASI, Menyusui \& SADARI. Yogyakarta : Nuha Medika

Maryunani, Anik. 2012. Inisiasi Menyusui Dini, ASI eksklusif dan Manajemen Laktasi. Jakarta : CV. Trans Info Media 2009. Asuhan Pada Ibu dalam Masa Nifas (Postpartum). Jakarta : CV. Trans Info Media

Notoatmodjo.2010.MetodelogiPenelitianKesehatan.Jakarta : RinekaCipta

Peraturan Pemerintah RI. 2012. Tentang Pemberian ASI Eksklusif. Diakses Kamis, 02 Maret 2017

Putri, A. 2013. Hubungan Pengetahuan Ibu Bekerja Tentang Manajemen Laktasi Dengan Perilaku Ibu Dalam Pemberian ASI. https://www.scribd.com/document/273019/asi diakses Jumat, 24 Maret 2017
Rahmawati, Eli. 2013. Hubungan Pijat Oksitosin Dengan Pengeluaran ASI Pada Ibu Postpartum Hari 1-2 DiBPMHj.NL kota Balikpapan Tahun 2013. https://husadamahakam.files.wordpress/2015/12/1jurnal-elly-u-nop-14-okdiakses Selasa, 06 Desember 2016

Roito, dkk. 2013. Asuhan Kebidanan Ibu Nifas \& Deteksi Dini Komplikasi. Jakarta : EGC

Sari, E.P \& Rimandini, K.D. 2014. AsuhanKebidanan Masa Nifas (Postnatal Care. Jakarta : CV. Trans Info Media

Satyagraha. 2014. BPS:Jumlah Penduduk Bekerja. Jakarta : ANTARA News (19 Maret 2017)

Suhardjo. 2010. Pemberian Makanan Pada Bayi dan Anak. Yogyakarta : Kanisius

Suherni,dkk. 2010. Perawatan Masa Nifas. Yogyakarta : Fitramaya

Sulistiyowati, T \&Siswantara, P. 2016. Perilaku Ibu Bekerja Dalam Memberikan ASI Eksklusif. Journal.unair.ac.id/download-fullpapersjupromkesd6de2ea109full.pdf diakses Minggu, 19 Maret 2017

Undang-undang 1945. 2015. Tentang Menyusui dan Bekerja. Diakses Minggu, 19 Maret 2017

http://menyusui.info/regulasi/undang-undang-danperaturan-tentang-menyusui-dan bekerja/

Wawan, A \& Dewi, M. 2011. Teori dan Pengukuran Pengetahuan, Sikap dan Perilaku Manusia. Yogyakarta : Nuha Medika

Yanti. 2009. Buku Ajar Asuhan Kebidanan Persalinan. Yogyakarta : Pustaka Rihama 